\title{
TOXIC AND ANTIFEEDING ACTIVITIES OF CERTAIN PLANT EXTRACTS AND THEIR EFFECTS ON BIOLOGICAL AND BIOCHEMICAL ASPECTS OF THE COTTON LEAFWORM SPODOPTERA LITTORALIS (BOISD.)
}

\author{
SHENODA S. YACOUB
}

Plant protection research institute, ARC, Dokki, Giza

(Manuscript received 23 January 2013)

\begin{abstract}
The present work aimed to study the toxic and antifeeding activities of certain plant extracts against Spodoptera littoralis (Boisd.) The extracts of lantana and lemongrass leaves were applied at $5 \& 10 \%$ concentrations, against $2^{\text {nd }}$ and $4^{\text {th }}$ instars larvae of $S$. littoralis under laboratory conditions $27 \pm 2{ }^{\circ} \mathrm{C}$ and 55 - $65 \%$ relative humidity. Results showed that the lemongrass extract in water at $10 \%$ conc. on the $2^{\text {nd }}$ larval instar and lantana extract in water at $10 \%$ conc. on $4^{\text {th }}$ larval instar were the highest in efficacy as antifeedants. Regarding, conversion of ingested and digested food (ECI) \& (ECD) lantana extract in water $10 \%$ had the least effect. The highest mortality percentage was attained from the lemongrass extract in acetone $10 \%$ and lantana extract in water $5 \%$ treatments against both the $2^{\text {nd }}$ and $4^{\text {th }}$ larval instars, respectively. Data showed that all the plant extracts caused significant reductions in respect of larval and pupal durations, pupal weight and \% of adult emergence compared with the untreated check. The plant extracts had a clear effect on the carbohydrates hydrolysis enzymes as amylase and trehalse.
\end{abstract}

\section{INTRODUCTION}

In Egypt, cotton leafworm, Spodoptera littoralis (Boisdural) [Lepidoptera: Noctuidae], is one of the most serious insect pest as it causes high damage levels to cotton plants and different cultivated crops beside to vegetables (Campion et. al., 1997 and Nasr et. al., 1984)

The use of antifeedants in pest control has attracted the attention of many workers and different compounds were used as inhibiting the feeding of chewing phytophagous insects. Botanical biocides today constitute a major and critical input in the organic products of agricultural and horticultural crops all over the world specially in the developing countries. Various problems associated with the misuse and excessive reliance of synthetic organic pesticides directed the urgent need for effective and selecting biocides (Asher, 1970).

The active principles of various plant materials show value and promise in integrated pest management (IPM), also they are considered soft and owe safer characters. The complex structure of biocomponents may decrease the likehood of rapid resistance development, they are biodegradable, the potential for compatibility 
with natural enemies exist and environmentally friendly materials (Kelany, 2001). In a field experiment the effect of ornamental plants on the Sesamia cretica infestation, Yacoub et. al., (2011) were examined.

Carbohydrates are one of the vital important since the insect body can utilize them for producing energy or converted to lipids or proteins. Metabolism of carbohydrates is controlled mainly by trehalase, amylase and invertase enzymes that play an important role in digestion and utilization of carbohydrates by insects (Wyatt, 1967).

The present work aimed to determine the efficacy of some plant extracts as antifeedants and their effects on biochemical properties against $S$. littoralis larvae.

\section{MATERIALS AND METHODS}

\section{Insects}

The tested insects were obtained from a culture of $S$. littoralis at the cotton pest research department - Plant Protection Research Institute Agriculture Research Center, Dokki, Giza -in which they were reared on fresh leaves of castor bean leaves Ricinus communis for several generations without any insecticidal pressure. The culture was reared under laboratory conditions ( $27 \pm 2^{\circ} \mathrm{C}$ and $55-65 \%$ R.H.).

\section{Preparation of plant extracts}

The scientific and English name of the extracted plant and the used parts are demonstrated in the following table:

\begin{tabular}{|l|l|l|l|}
\hline Scientific name & Family & English name & Part used \\
\hline Lantana salvifolia & Verbenaceae & Lantana & Leaves \\
\hline Cymbogon citrates & Gramineae & Lemongrass & Leaves \\
\hline
\end{tabular}

The plant leaves were cleaned, water rinsed then spread for drying in shade at room temperature for $2-3$ weeks for dryness, after that the leaves were finely grained. To obtain the two used concentration 5 and 10\%, $50 \mathrm{gm}$ of dried leaf powder were mixed with 1000 and $500 \mathrm{ml}$ of boiled water, respectively, stirred after stoppering the container tightly. The resulting solutions were kept at $5^{\circ} \mathrm{C}$ until using, as described by Emara et. al., (1994).

For preparing the extracts with acetone, the grounded plant leaves were mixed with the polaric organic solvent acetone at ratio of $1 \mathrm{gm}$ of leaf powder : $2 \mathrm{~cm}^{3}$ solvent, blended at high speed electric blender for 15 minutes then filtered. The solvent was evaporated by the aid of an electric fan. All extracts were kept in the refrigerator at $-4^{\circ} \mathrm{C}$. 


\section{Feeding deterrent and consumption of plant extracts}

Antifeedant experiments were carried out using $2^{\text {nd }}$ and $4^{\text {th }}$ instar larvae of $S$. littoralis obtained from a laboratory culture. One hundred and eighty larvae were starved for 3 hours before the beginning of the experiment, divided into 4 replicates each contained 5 larvae for each treatment and all larvae were weighed. For the control, the same number of replications were kept in similar containers in which the larvae were supplied with the untreated castor leaves. Fresh castor leaves were dipped for 10 seconds in the different plant extracts. The treated leaves were left in shade to dry. Each larva was daily weighed for 3 days. The amount of consumed food and larval weight were calculated. The larvae and the amount of feaces were daily weighed. The antifeedant index (AFI) was calculated according to Sadek (2003).

AFI $=[(C-T) /(C+T)] \times 100$

$C$ : food consumed (leaves) in the control

$\mathrm{T}$ : food consumed (leaves) in the treatment

Efficacy of conversion of ingested food (ECI) and efficacy of conversion of digested food (ECD) were calculated by Woldbauer, (1968) and Farra et. al., (1989)

where:

$\mathbf{E C I}=(\Delta \mathrm{B} / \mathrm{I}) \times 100, \mathbf{E C D}=[\Delta \mathrm{B} /(\mathrm{I}-\mathrm{F})] \times 100, \mathbf{I}$ : weight of food consumed, Ba: mean of insect weight during the experiment,

T: feeding period in days, $\mathbf{\Delta} \mathbf{B}$ : change in body weight, F: weight of feaces produced during the feeding period

\section{Biological studies}

Laboratory experiments were conducted to determine the antifeedant and toxic activity of the forementioned extracts against $2^{\text {nd }}$ and $4^{\text {th }}$ instar of $S$. littoralis larvae reared at $27 \pm 2{ }^{\circ} \mathrm{C}$ and $55-65 \%$ R.H. All experiments were carried out using dipping method, in which fresh castor leaves were dipped for 20 seconds in the different tested extracts. Then they were left in shad to dry. Two hundred and seventy larvae were divided into three replicates each of 10 larvae where they were kept in plastic cups. 
Larval mortality was daily recorded until pupation. Mortality percentage was determined according to Meglla (1984) and corrected percentage mortality was determined according to Abbott's formula (1925):

$\%$ Mortality $=$ No. of dead larvae $\quad X 100$

Total No. of larvae

Corrected \% mortality $=\underline{X-Y} \quad X 100$ $100-Y$

$\mathrm{X}: \%$ mortality in treatment

$Y: \%$ mortality in check

The duration of larvae and pupae were determined. Also, percentage of malformed pupae, pupal weight and adult emergence were calculated.

$\%$ Malformed pupae $=\underline{\text { No. of malformed pupae }} \times 100$

Total No. of pupae

$\%$ Emergence $=\underline{\text { No. of emerged adults }} \times 100$

Total No. of adults

\section{Statistical analysis}

The obtained data of the biological studies were statistically analyzed through Excel program for Windows 7 computer to determine the $F$ value and least significant difference L.S.D. at $0.05 \%$ confidence degree.

\section{Biochemical studies}

\subsection{Chemicals}

Bovine albumin standard was purchased from Stanbio laboratory (Texas, USA). Commasie brilliant blue G-250 was obtained from sigma (Sigma Chemical Co.). P- nicotina (purity 97\%) was obtained from Ubichem Ltd. (Ham pshire), while nicotinamide ademine dinucleotide phosphate (reduced form, NADP. $\mathrm{H}_{2}$ ) was supplied from BDH chemicals Ltd. (Poole, England).

\subsection{Apparatus}

Telfon tissue homogenizer (ST-2 Mechanic-Preczyina, Poland). After homogenation, supernatants were kept in a deep freezer at $-20{ }^{\circ} \mathrm{C}$ till use for biochemical assays. Double beam ultraviolet / visible spectrophotometer (spectronic 1201, Milton Roy Co. USA) was used to measure absorbance of colored substances or metabolic compounds. 


\subsection{Preparation of insects for analysis}

The insects were homogenized in distilled water $(50 \mathrm{mg} / 1 \mathrm{ml})$ for biochemical analysis in a chilled glass. Homogenates were centrifuged at 8000 r.p.m. for $15 \mathrm{~min}$ at $5^{\circ} \mathrm{C}$ in a refrigerated centrifuge. The deposits were discarded and the supernatants were kept in a deep freezer till use.

\subsection{Determination of tested enzymes}

\subsubsection{Amylase \& trehalase determination}

Digestive enzymes were determined according to the method described by Ishaaya and Swirski (1976) using trehalose, sucrose and soluble starch as substrates for trehalase, invertase and a-amylase, respectively. Generally, $20 \mu \mathrm{l}$ of diluted enzyme solution was incubated for $10 \mathrm{~min}$ at $30{ }^{\circ} \mathrm{C}$ with $250 \mu \mathrm{l} \%$ starch (soluble potato starch - Lintner grade - Sigma Chemical Co.) in $50 \mathrm{mM}$ acetate buffer pH 5.0 containing $20 \mathrm{mM} \mathrm{NaCl}$ and $0.1 \mathrm{mM} \mathrm{CaCl} 2$. The reaction was stopped by adding $250 \mu \mathrm{l}$ DNS reagent to each tube in boiling water for $5 \mathrm{~min}$. Samples were cooled diluted with $2.5 \mathrm{ml} \mathrm{H} \mathrm{H}_{2} \mathrm{O}$ and read at $550 \mathrm{~nm}$ on Spectronic 1201 (Beckman, USA).

Glucose was used as a standard. Appropriate dilutions of enzyme supernatant to obtain a linear production of glucose equivalents.

Generally, for each test amylase activity was determined from triplicate analyses of three groups of seedlings. The enzyme activity was expressed as $\mu \mathrm{g}$ glucose released / min / gm fresh weight.

\section{Statistics}

The results were analyzed by one - way of variance (ANOVA) using costat statistical software (cohort software, Berkeley). When the ANOVA statistics were significant $(p<0.01)$ and means were compared by the Duncan's multiple range test.

\section{RESULTS AND DISCUSSION}

\section{The antifeedant properties of different plant extracts}

Antifeedant effects of the plant extracts against $2^{\text {nd }}$ and $4^{\text {th }} S$. littoralis larvae were estimated and calculated after 24, 48 and 72 hours from the beginning of the experiment through the consumption of treated leaves of castor oil beans (Table, 1). It is worth to note that (AFI) values increased with the increase of tested concentration of used plant extracts. The rate of increase was progressively recorded by elapse of time after applications showing $27.78-61.53,36.67-63.73$ and $41.09-$ $78.24 \%$ for first, second and third days, respectively, for the $2^{\text {nd }} S$. littoralis larval instar. While, for the $4^{\text {th }}$ larval instar, the AFI values ranged from $12.75-36.87,13.02$ - 51.58 and $25.14-59.28 \%$ for the previous three days, respectively (Table, 2 ). 
Lemongrass extract in water at $10 \%$ concentration caused the highest antifeedant activity being $61.53,63.73$ and $78.24 \%$ three days after inspection for $2^{\text {nd }}$ instar larvae. In case of $4^{\text {th }}$ instar larvae lantana extract in water $10 \%$ caused the highest antifeedant efficacy being $36.87,51.58$ and $59.28 \%$ for the three days, respectively.

On the contrary, lemongrass extract in acetone at $5 \%$ had the lowest antifeedant value among all the tested extracts achieving 27.87, $36.67 \& 41.09 \%$ for $2^{\text {nd }}$ larval instar and $12.75,13.02$ and $25.14 \%$ for the $4^{\text {th }}$ instar after 1,2 and 3 days, respectively.

\section{Efficacy of the conversion of ingested and digested food (ECI) \& (ECD)}

All the tested extracts reduced the nutritional indices ECI \& ECD in either of $2^{\text {nd }}$ and $4^{\text {th }}$ instar larvae. Data in table (2) clearly showed that the values of the two parameter - conversion of ingested food (ECI) and conversion of digested food (ECD) for $2^{\text {nd }}$ and $4^{\text {th }}$ larval instar were $(12.6-16.31 \%) \&(22.79-27.94 \%)$ for lantana extract in water $10 \%$, respectively. Followed by the same extract at $5 \%$ concentration being $(15.60-22.61 \%)$ for the $2^{\text {nd }}$ larval instar, lemongrass extract in acetone $10 \%$ $(30.7-33.18 \%) 4^{\text {th }}$ larval instar, respectively. While the maximum percentages for these parameter were recorded in the control achieving $(33.35-73.64 \%) \&(63.54-$ $90.86 \%)$, respectively.

The role of deterrents i.e. secondary plant substances inhibiting feeding or oviposition (Fenny et. al., 1988). These results were coincided with that reported by El-Gegahi et. al., (1996) who found a significant reduction in the food consumption and a considerable decrease in the larval body weight $4^{\text {th }} S$. littoralis larval instar. The same author reported that the bestachia crude extract reduced consumption growth, utilization of ingested and digested food.

\section{Biological effects of treated extracts on the $2^{\text {nd }}$ and $4^{\text {th }}$ larval instars $S$. littoralis which treated}

\section{3.a. Effect on percentage mortality}

Data in Table (3), showed that the highest mortality percentage was obtained from treatment of $2^{\text {nd }}$ larval instar of $S$. littoralis at $10 \%$ concentration of lemongrass in acetone followed by lantana extract in water $5 \%$ causing exhibiting $73.32 \%$ mortality.

On the other hand, for the $4^{\text {th }}$ instar the highest percentage larval mortality was $70.73 \%$ by lantana extract in water at $5 \%$ concentration followed by lemongrass extract in acetone $10 \%$ causing $68.75 \%$ larval mortality. The remaining six extracts could be classified into two groups, the first had an intermediate effect as lantana extract in acetone and water both of them at $10 \%$ concentration and lantana extract in acetone $5 \%$ being $64.15,64.15$ and $54.15 \%$ for $2^{\text {nd }}$ larval instar. In case of the $4^{\text {th }}$ 
instar larvae it caused $67.9,64.15$ and $64.15 \%$ mortality, respectively. The second group which had low effect on the percentage mortality including lemongrass extract in water at $5 \& 10 \%$, lemongrass extract in acetone at $5 \%$ recording $40.83,39.58$ and $25.83 \%$ mortality for $2^{\text {nd }}$ larval instar larvae and $39.58,55.8$ and $35 \%$ mortality for $4^{\text {th }}$ larval instar larvae, respectively, Table (3).

\section{3.b. Larval duration}

Data presented in table (3) showed that the effect of plant extracts on larval duration as one of the biological activities of $S$. littoralis larvae, representing significant differences at $(P<0.05)$ with averages 14.75 and 14.25 days for lantana extract in water and lemongrass extract in acetone at $5 \%$ conc., respectively. While, the shortest mean of larval duration resulted from treatment by lemongrass extract in water $10 \%$ ( 8.75 days) opposite to ( 21.25 days) for the untreated check followed by lemongrass extract in water at $5 \%$ (9.75 days). The remaining tested extracts achieved averages of larval duration ranged from 10.25 days by lantana extract in acetone to 13.25 days for lantana extract in water both of them at $10 \%$ concentration.

\section{3.c. Pupal duration}

As shown in Table (3), all extracts reduced the pupal period (8.5 - 12.25 days) when compared with the check (14.25 days). The longest pupal period (12.25 days) resulted from the treatment of lemongrass extract in water $10 \%$, followed, insignificantly by lantana extract in acetone $5 \%$ (12 days) and lantana extract in water $10 \%$ (11.75 days). Lantana extract in water $5 \%$, in acetone $10 \%$ and lemongrass extract in acetone $5 \%$ led to a approximately similar pupal period showing $9.75,9.75$ and 10 days, respectively. While, lemongrass and lantana in acetone $10 \%$ caused a high significant pupal period 8.5 and 9.75 days, opposite to 14.25 days for the check.

\section{3.d. Pupal weight}

Data in Table (3) indicated that all treatments caused high significant reductions in the pupal weight averaged from 0.2131 to $0.2997 \mathrm{gm} /$ pupa opposed to $0.3105 \mathrm{gm}$ in the check. The highest effect was recorded in case of lantana extract in water $5 \%(0.2131 \mathrm{gm})$ followed insignificantly by lemongrass extract in acetone $10 \%$ $(0.2311 \mathrm{gm})$, lantana extract in acetone $5 \%(0.2444 \mathrm{gm})$ and lantana extract in water $10 \%(0.2591 \mathrm{gm})$. On the contrary, the lowest effect on the weight was proved with lantana extract in acetone $10 \%$ and lemongrass extract in water $10 \%$, respectively, (0.2928 and $0.2997 \mathrm{gm})$.

\section{3.e. Pupal malformation}

As. Shown in Table (3), all treatment caused high significant pupal malformation and all the malformed pupae showed clearly deformities than the check. 
The highest percentage of malformation was $77.05 \%$ resulted from lemongrass extract in acetone $10 \%$ followed insignificantly by lantana extract in acetone $10 \%$ $(73.75 \%)$, the same extract in water $5 \%$ caused $71.65 \%$. The remaining extracts were lemongrass in water $5 \% \& 10 \%$ resulted ( $59.13 \& 58.28 \%$ malformed pupae) in which they were considered to have intermediate effect and had significant percentage with the highest percentages of malformed pupae.

Malformations of $S$. littoralis pupae mostly appeared with different degrees of abnormalities of body shrinkage, moulting integument remain with pupae and colored by black, larval cuticle remain patches and moulting failure at the last instar larvae.

\section{3.f. Adult emergence}

Data presented in Table (3), showed that the lowest percentage of adult emergence resulting from treating larvae with the tested extracts recording $18.33 \%$ as a result of lemongrass extract in acetone $10 \%$. Insignificantly, followed by lantana extract in acetone $10 \%(25.83 \%)$. The remaining extracts could be classified into two groups the first had intermediate effect on percentage of emergence including lemongrass extract in acetone $5 \%(29.15 \%)$, lemongrass extract in water $5 \%$ (29.15\%) and lantana extract in water 10\% (31.22\% adult emergence), respectively. The second group represented by lantana extract in acetone $5 \%(49.98 \%)$ and lemongrass extract in water $10 \%$ (58.30\%) while the percentage was $93.23 \%$ for the control.

These results are in agreement with that of Gaaboub et. al., (2005) who examined the activity of the biochemical extracts from Neotorularia aculeolata against $4^{\text {th }}$ instar larvae of $S$. littoralis using five solvents differ in their polarity (benzene, ethyl acetate, chloroform, ethanol and water) and all caused the high mortality percentages and antifeedant activity. Recently, Rajapaksa and Ratnasekera (2008) obtained plant oils from leaves of lemongrass and they were used to protect stored legumes against cowpea weevil and bean seed weevil and it caused significant adult mortality and reducing egg production. Amany. S. El-Hefny et. al., (2011) stated that leaves of lantana extract in acetone achieved reductions in mealy bug population.

\section{Biochemical studies}

\section{4.a. Amylase enzyme assessment}

Table (4), showed changes in the rate of amylase enzyme when it was determined in the $2^{\text {nd }} S$. littoralis larval instar after treatments with the tested extracts. Lantana extract in water at $5 \%$ decreased the amylase activity achieving $158.33 \mu \mathrm{g}$ glucose with $35.37 \%$ opposite to check which achieved $245 \mu \mathrm{g}$ glucose. On the contrary, the highest concentration (10\%) from the same extract caused 247.66 $\mu \mathrm{g}$ glucose. From these results it was clear that the increase amylase enzyme activity 
increase was correlated positively with the increase concentration of the same plant extract. In case of $S$. littoralis $4^{\text {th }}$ instar larvae the results showed that lantana extract in water $10 \%$ achieved $\mu \mathrm{g}$ glucose decrease in mean of amylase enzyme (188 $\mu \mathrm{g}$ glucose. For the lemongrass extract in acetone $10 \%$ it caused $334.33 \mu \mathrm{g}$ glucose in comparison with the check that was $227 \mu \mathrm{g}$ glucose.

\section{4.b. Trehalase enzyme assessment}

Table (4), showed the activity of trehalase enzyme was differed based on the treated extracts against $2^{\text {nd }}$ instars larvae. Lantana extract in water at both concentrations $5 \& 10 \%$ caused 415.33, $627 \mu$ g glucose, respectively.

Also, for $4^{\text {th }} S$. littoralis larval instar Lantana extract in water $10 \%$ caused 442 $\mu \mathrm{g}$ glucose and lemongrass extract in acetone $10 \%$ achieved $926.33 \mu \mathrm{g}$ glucose, while the rate of trehalase was $794 \mu \mathrm{g}$ glucose in the check. The results obtained was in the same trend with that recorded by Mead et. al., (2008) who observed a pronounced decrease in the carbohydrate hydrolyzing enzymes activity especially amylase and invertase after treating $S$. littoralis $4^{\text {th }}$ larval instar with spinosad and triflumuron either alone or as mixture with the two surfactants Triton X -100 and Tween -20 causing a high significant decrease in the enzymes activity.

5. Correlation between food consumption, AFI parameters and the carbohydrate hydrolyzing enzymes at $\mathbf{2}^{\text {nd }} \boldsymbol{\&} \mathbf{4}^{\text {th }} S$. littoralis larval instar

Data presented in Table (5), demonstrated that the percentage of consumption of ingested food (ECI) had a positive relationship with the activity of the amylase and trehalase enzymes $r^{2} 0.59042$ and 0.66277 for the $2^{\text {nd }} S$. littoralis and for $4^{\text {th }}$ S. littoralis instars 0.256529 and 0.3813243 , respectively.

The efficacy of consumption food (ECD) had direct proportion with the activity of the amylase and trehalase enzymes achieving positive $r^{2}$ values being 0.687521 , 0.751347 for and $0.351805,0.4717701$ for $4^{\text {th }} S$. littoralis, respectively, (Table 6).

On the other hand, the percentage of antifeedant index (AFI) had an absolute positive relationship with the amylase and trehalase enzymes for the $2^{\text {nd }} S$. littoralis instar in which $r^{2}=1 \& 1$, respectively. Opposite to that obtained in $4^{\text {th }} S$. littoralis instar AFI had an absolute negative relationship with the same two enzymes $r^{2}=(-$ $1 \&-1)$, respectively.

Hendy et. al., (1994) examined the toxic of hexan and chloroform dodonia extract against $S$. littoralis larvae and recorded in adults emergence being $60 \%$, percentage pupation and number of egg deposited were decreased. Finally, the authors stated that dodonia had a repellent effect on $S$. littoralis adults. 
Table. 1. Parameters the efficiency against of some extracts S. littoralis 2 nd instar larvae.

\begin{tabular}{|c|c|c|c|c|c|c|c|}
\hline \multirow{2}{*}{ Treatments } & \multirow{2}{*}{$\begin{array}{c}\% \\
\text { conc. }\end{array}$} & \multicolumn{4}{|c|}{ AFI days after treatment } & \multirow{2}{*}{ ECI \% } & \multirow{2}{*}{ ECD \% } \\
\hline & & 1 & 2 & 3 & Mean & & \\
\hline \multirow{2}{*}{$\begin{array}{c}\text { Lantana extract in } \\
\text { water }\end{array}$} & 5 & 32.32 & 39.30 & 53.76 & 41.79 & 15.60 & 22.61 \\
\hline & 10 & 53.09 & 55.98 & 60.02 & 56.36 & 12.60 & 16.31 \\
\hline \multirow{2}{*}{$\begin{array}{l}\text { Lantana extract in } \\
\text { acetone }\end{array}$} & 5 & 46.26 & 48.39 & 48.44 & 47.69 & 27.58 & 33.85 \\
\hline & 10 & 61.20 & 63.21 & 64.38 & 62.93 & 22.90 & 33.01 \\
\hline \multirow{2}{*}{$\begin{array}{l}\text { Lemon-grass extract } \\
\text { in water }\end{array}$} & 5 & 42.84 & 54.41 & 54.99 & 50.74 & 27.99 & 38.25 \\
\hline & 10 & 61.53 & 63.73 & 78.24 & 67.77 & 17.40 & 31.61 \\
\hline \multirow{2}{*}{$\begin{array}{c}\text { Lemon-grass extract } \\
\text { in acetone }\end{array}$} & 5 & 27.78 & 36.67 & 41.09 & 33.84 & 19.40 & 32.52 \\
\hline & 10 & 52.75 & 53.13 & 56.50 & 54.12 & 23.35 & 38.29 \\
\hline Check & & - & - & - & - & 33.35 & 73.64 \\
\hline
\end{tabular}

AFI : $\quad$ Antifeedant index

ECI: $\quad$ Efficacy of conversion of ingested

ECD: Efficacy of conversion of digested food

Table. 2. Parameters of the efficiency of some extracts against S.littoralis 4th instar larvae.

\begin{tabular}{|c|c|c|c|c|c|c|c|}
\hline \multirow{2}{*}{ Treatments } & \multirow{2}{*}{$\begin{array}{c}\% \\
\text { conc. }\end{array}$} & \multicolumn{4}{|c|}{ AFI days after treatment } & \multirow{2}{*}{ ECI \% } & \multirow{2}{*}{ ECD \% } \\
\hline & & 1 & 2 & 3 & Mean & & \\
\hline \multirow{2}{*}{$\begin{array}{c}\text { Lantana extract in } \\
\text { water }\end{array}$} & 5 & 12.89 & 18.70 & 29.66 & 20.41 & 33.70 & 49.86 \\
\hline & 10 & 36.87 & 51.58 & 59.28 & 49.24 & 22.79 & 27.94 \\
\hline \multirow{2}{*}{$\begin{array}{c}\text { Lantana extract in } \\
\text { acetone }\end{array}$} & 5 & 22.24 & 23.48 & 25.37 & 23.69 & 44.89 & 49.56 \\
\hline & 10 & 25.51 & 30.29 & 33.18 & 29.66 & 39.52 & 41.75 \\
\hline \multirow{2}{*}{$\begin{array}{c}\text { Lemon-grass extract } \\
\text { in water }\end{array}$} & 5 & 20.20 & 24.23 & 31.68 & 25.37 & 34.55 & 44.14 \\
\hline & 10 & 25.65 & 26.21 & 32.59 & 28.15 & 38.68 & 39.86 \\
\hline \multirow{2}{*}{$\begin{array}{c}\text { Lemon-grass extract } \\
\text { in acetone }\end{array}$} & 5 & 12.75 & 13.02 & 25.14 & 16.97 & 35.48 & 47.18 \\
\hline & 10 & 35.30 & 39.89 & 57.87 & 44.35 & 30.70 & 33.18 \\
\hline Check & & - & - & - & - & 63.54 & 90.86 \\
\hline
\end{tabular}

AFI : $\quad$ Antifeedant index

ECI: $\quad$ Efficacy of conversion of ingested food

ECD: Efficacy of conversion of digested food 
Table. 4. Effect of plant extracts on Amylase and Trehalse enzymes; of the 2nd \& 4th instar larvae of $\mathrm{S}$. littoralis.

\begin{tabular}{|c|c|c|c|}
\hline \multirow{4}{*}{} & \multirow{2}{*}{ Treatments } & \multicolumn{2}{c|}{ Mean of } \\
\cline { 3 - 4 } & & Amylase & Trehalse \\
\cline { 3 - 4 } $2^{\text {nd }}$ & Lantana extract in water 5\% & 158.33 & 415.33 \\
\cline { 2 - 4 } instar & Lantana extract in water 10\% & 247.66 & 627 \\
\cline { 2 - 4 } & Control & 245 & 644 \\
\hline \multirow{3}{*}{$4^{\text {th }}$} & Lantana extract in water10\% & 188 & 442 \\
\cline { 2 - 4 } instar & Lemongrass extract in acetone 10\% & 334.33 & 926.33 \\
\cline { 2 - 4 } & Control & 277 & 794 \\
\hline
\end{tabular}

Table. 5. Correlation coefficient between certain parameters against 2 nd and 4th instar of S. littoralis.

\begin{tabular}{|c|c|c|c|}
\hline \multirow{2}{*}{ Larval instar } & \multirow[t]{2}{*}{ Parameters } & \multicolumn{2}{|c|}{ Coefficient of correlation $r^{2}$} \\
\hline & & amlayse & trehalse \\
\hline Second instar & \multirow{2}{*}{ AFI } & 1 & 1 \\
\hline Fourth instar & & -1 & -1 \\
\hline Second instar & \multirow{2}{*}{ ECI } & 0.59042193 & 0.66277773 \\
\hline Fourth instar & & 0.25652960 & 0.38132430 \\
\hline Second instar & \multirow{2}{*}{ ECD } & 0.68752170 & 0.751947510 \\
\hline Fourth instar & & 0.35180520 & 0.471770184 \\
\hline
\end{tabular}




\section{REFERENCES}

1. Abbott, W.S. 1925. A method of computing the effectiveness of an insecticides, J. Econ. Entomol. 18: 265 - 672.

2. Amany S. EL-Hefny, Omnia M. N. EL-Sahn and SH.S. Yacoub. 2011. Effect of some plant extracts on citrus mealy bug Planococcus citri (risso) Egypt, J. Agric. Res., 89(2): 511 - 519.

3. Asher, K.R.S. 1970. Insect pest control by chemosterilants and antifeedant WLD. Rev. Pest Control, IX No. 4: 140 - 145.

4. Campion. D.G., B.W., Bettany, J.B., McGinnigle and L.R. Tailor. 1997. The distribution and migration of Spodoptera littoralis (Boisduval) (Lepidoptera: Noctuidae), in relation on Cyprus, interpreted from maps of pheromone trapa samples, Bull. Ent. Res. 67, 501 - 522.

5. Emara, M.M., A.G. El-Sisi and S.A. Mahmoud. 1994. Formulation and evaluation of certain local natural products against Varroa, a mite infesting bee colonies. J. Agric. Sci. Mansoura Univ., 19(5): 1843 - 1850.

6. El-Gegahi, S.C., I.A. Ismail and G. Atwa. 1996. Anti insect properties of the Antholyza ricngens Andr. (Family: Iridacea) rxtracts for ovicidal effect on the rice moth Corcya cephalonica (Staintion). Pest, Management and Econ. Zoology, 5(1): $53-55$.

7. Farra, R.R., J.D. Barbour and G.G. Kenedy. 1989. Quantifying food consumption and growth in insects. Ann Entomol. Soc. Am 82: 593 - 598.

8. Feeny, P., K. Sachdev-Gupta, L. Rosenberry and M. Carter. 1988. Luteolin 7-o(6-O- malonyl)- $\beta$-D-glucoside and trans-chlorogenic acid oviposition stimulants for the black swallowtail butterfly. Phytochemistry, 27, 3439 - 3449.

9. Gaaboub, I., Safaa Halawaa, Ahmed, F. EL-Aswad and Enas, M. Khamis. 2005. Feeding deterrent and growth inhibitory properties of Neotorularia aculeolata against the cotton leaf worm Spodoptera littorallis (Boisd.), Egypt, J. Agric. Res., 83(3): $973-986$.

10. Hendy, Z.H., G. El-Saadany, A. Sharaby, E.A. Omer and S. Abd-El-Azia. 1994. Biological activity of essential oil of Dodonia viscose plant against the cotton leafworm, Spodoptera littoralis boisd, Conference of Agricultural Development Research, Cairo (Egypt), 20 - 22 Dec.

11. Kelany, I.M. 2001. Plant extracts and utilization of their products for safe agricultural production and for reducing environmental pollution proceedings of the 10th workshop. pp $6-14$. 
12. Khamis. 2005. Feeding deterrent and growth inhibitory properties of Neotorularia aculeolata against the cotton leafworm, Spodoptera littoralis (Boisd.), Egypt, J. Agric. Res., 83(3): 973 - 986.

13. Hala, M. Mead, A.A. El-Sheakh, B.A. Soliman, W.M.H. Desuky and A.H. AboGhalia. 2008. Biochemical effect of some compounds on carbohydrate hydrolyzing enzymes of cotton leafworm, Spodoptera littoralis (Boisd.) Egypt, J. Agric. Res., 86(6): $2169-2179$.

14. Ishaaya, I. and E. Swirski. 1976. Trehalase, invertase and amylase activities in the black scale Saissetia oleae, and their relation to host adaptability. J. Insect Physiol. 22: 1025 - 1029.

15. Megalla, A. E. 1984. Effect of certain dietary constituents aan silkworm Ph. D. Thesis, Fac. Of Agric. Ain Shamas Univ. Egypt.

16. Nasr, E.A., M.R. Tucker, and D.G. Campion. 1984. Distribution of moths of the Egyptian cotton leafworm, Spodoptera littoralis (Boisduval) (Lepidoptera: Noctuidae), in the Nile Delta interpreted from catches in a pheromone trap network in relation to meteorolgical factors. Bull. Ent. Res. 74: 487 - 494.

17. Rajapakse, R.H.S. and D. Ratnasekera. 2008. Pesticidal of some selected tropical plant extracts against Callosobruchus maculates F. and Callosobruchus chinensis L. (Coleoptera: Bruchidae). Tropical Agricultural Research, 11(1).

18. Sadek, M., M. 2003. Antifeedant and toxic activity of Adhatoda vasica leaf extract against Spodoptera littoralis (lep. Noctuidae) . Appl. Ent. 127(1): 396 404.

19. Waldbauer, G.P. 1968. The consumption and utilization of food insects. Adv. Insect Physiol. 5: $229-288$.

20. Wyatt, G.R. 196. The biochemistry of sugar and polysaccharides in insect Adv. Insect Physiol. 4: $287-360$.

21. Yacoub, Sh., Amany S. EL-Hefny and Rasha A. EL-Hosary. 2011. Intercropping of some ornamental plants in corn field to reduce Sesamia cretica led. infestation Egy (89): $113-120$. 


\title{
خواص السمية ومانعات التظذية لبعض المستخلصات النباتية وتأثيراتها البيولوجية والبيوكيميائية على يرقات دودة ورق القطن
}

\author{
شنـوده سيد يعقوب \\ معرد بحوث وقاية النباتات - مركز البحوث الزراعية - الدقى - الجيزة
}

تم اختبـار تأثير بعض مستخلصـات أوراق نباتى اللانتانـا وحشيشــة الليهون اللذين ينتميـان لعائلتين نباتين مختلفتين بمذييين (الماء والاسيتون) بتركيزين مختلفين على العمر الثانى والرابع ليرقات

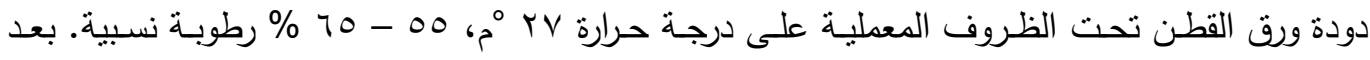

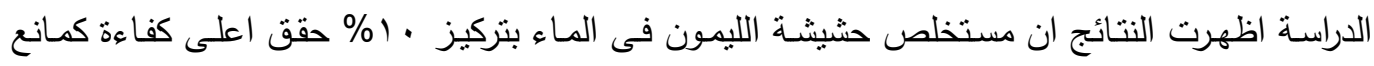

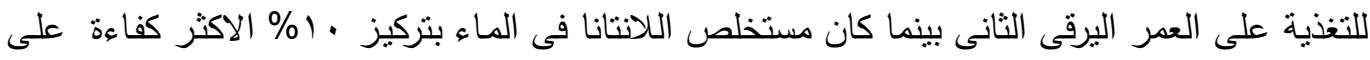

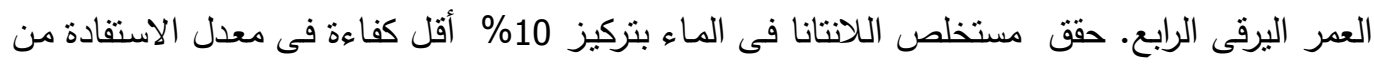

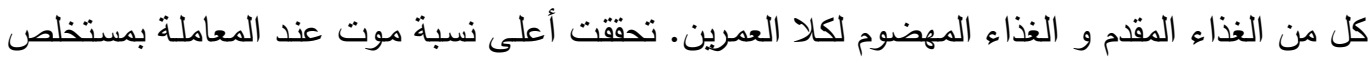

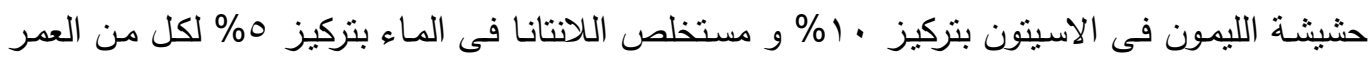

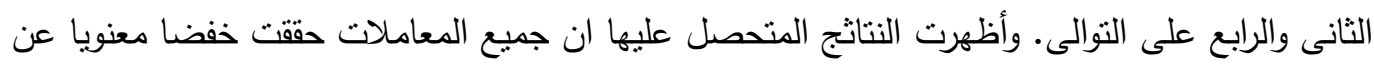

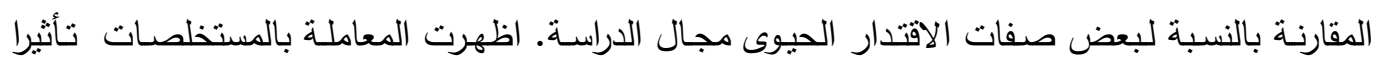
واضـحا على الانزيمـات المحلـة للكربوهيدرات مثنل الاميليز والتربهـاليز ليرقـات العمـر الثنانى والرابـع. اوضحت دراسة الارتباط دراسـة الارتباط العلاقة بين كفاءة هذه المستخلصـات كمانعات تغذيـة والقدرة

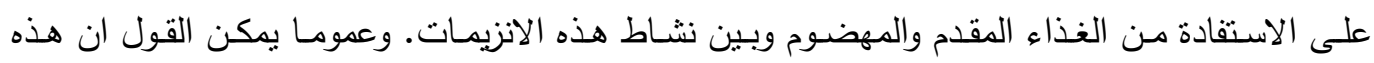
المستخلصـات النباتية ذات كفاءة عالية في مكافحة دودة ورق القطن بحسب نوع المذيب ونسبة التركيز 